CATALAN REVIEW

Catalan Review

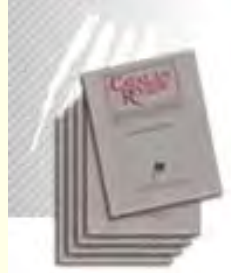

You are accessing the Digital Archive of the Catalan Review Journal.

By accessing and/or using this Digital Archive, you accept and agree to abide by the Terms and Conditions of Use available at http://www.nacs-

catalanstudies.org/catalan_review.html

Catalan Review is the premier international scholarly journal devoted to all aspects of Catalan culture. By Catalan culture is understood all manifestations of intellectual and artistic life produced in the Catalan language or in the geographical areas where Catalan is spoken. Catalan Review has been in publication since 1986 .
NORTH

AMERICAN

CATALAN

SOCIETY
Esteu accedint a l'Arxiu Digital del Catalan Review

A l' accedir i / o utilitzar aquest Arxiu Digital, vostè accepta i es compromet a complir els termes i condicions d'ús disponibles a http://www.nacs-

catalanstudies.org/catalan_review.html

Catalan Review és la primera revista internacional dedicada a tots els aspectes de la cultura catalana. Per la cultura catalana s'entén totes les manifestacions de la vida intel lectual i artística produïda en llengua catalana o en les zones geogràfiques on es parla català. Catalan Review es publica des de 1986.

\title{
The Process of Development of a Poem Carles Miralles
}

Catalan Review, Vol. I, number 1, (1986), p. 83-106 


\section{THE PROCESS OF DEVELOPMENT OF A POEM}

\section{CARLES MIRALLES}

Foix's poetic works (and that includes, of course, both his books of verse and his prose poetry), despite their complexity and richness, and the internal coherence of the whole are, basically, always the same. Even the form in which the poet has presented his work (texts from years ago side by side with recent texts, presented as a whole, together in the same book) reinforce this idea: that over the years Foix's poetry has not changed (within the context, of course, of the undeniable complexity and richness of his work).

I'm certain that the majority of Foix's readers have come to this same conclusion, an idea reinforced by his texts and encouraged by Foix himself, outside the confines of his poetry. Foix was making a statement when he chose an article written in $1935^{1}$ as the prologue for a book that was published in 1970 , as well as when he published collections which included articles, conference notes, etc., written almost forty years earlier. ${ }^{2}$ It was as though he were winking at the reader and saying: "You see? I'm the same Foix, and what I wrote years ago is still valid; I can publish it as if I had written it yesterday." It

1 The article, which appeared in Quaderns de Poesia, 6, 1935, entitled "Poesia i Revolució", was reproduced by the author under the title "Del real poètic", as a prologue to the book Darrer comunicat, Barcelona, 1970. The same is true of the text which serves as the prologue to Tocant a mà..., Barcelona, 1972, which was also first published in the same magazine, during the same year.

${ }^{2}$ For example, a book which I think is very important vis-à-vis Foix's poetry is Mots $i$ maons o a cascú el seu, Barcelona, 1971. 
is a statement, clearly, about "l'obra ben feta" ("a well-done work", a perfectionist notion of what constitutes a valid work, a very noucentista idea).

According to Foix, the poet - a witness of the passage of time - doesn't write specifically for today or for tomorrow. Thus, after many centuries, Llull's doctrine ${ }^{3}$ is "still very much alive" just as his Catalan is still "modern"; and if that is the case, should the poet be concerned about a mere thirty or forty years? Of course not, if he/she has something to say and knows how to say it.

My point, which in part is easily verified and in part is speculation, does not mean to imply that there are no differences between his books of verse and his books of prose poetry, in spite of the fact that many of Foix's poems are prefaced with what are, in fact, short prose poems themselves. Nor does it imply that certain distinctions can not be made on the basis of chronology - at least in terms of dates of publication among his books of prose poetry or among his books of verse.

The prevailing current critical position vis-à-vis Foix seems to be that the books of prose poetry which he published after 1956 are, in certain respects, different from the two he had published twenty-five years earlier. ${ }^{4} \mathrm{~A}$ discussion of the evolution of this work - and the nature of this evolution -5 would be a very different matter. Any reader of Foix would agree that there are few differences to be found in comparing Gertrudis and $K R T U$, on one hand, and those books published after,

3 Taken from an article in the newspaper La Publicitat, from December 18, 1934; used in J. V. Foix, Els lloms transparents, Barcelona, 1969 (the cited text taken from page 79).

${ }^{4}$ Pere Gimferrer, La poesia de J. V. Foix, Barcelona, 1974. See page 39 and the appropriate entry in the bibliography; and cfr. 99.

5 Enric Sullà in Serra d'Or, January 1973, 51. 
including From the 1918 Diary, on the other hand. That does not mean, however, that upon a close reading of all of these books it would not be possible to identify at least two differences between the latter group and the former group. In the first place, those books published after 1956 have a more narrative structure and, secondly, they say more, both conceptually and ideologically. Perhaps we are talking about one and the same thing: they have more to say in general and are, therefore, better able to articulate concepts just as they are to relate more to the reader.

Pere Gimferrer, in confirming these differences, which had been pointed out years earlier (see note 4) suggests that they are a manifestation of the poet's maturity. Indeed this is true, but it is important to make clear that the issue is not just about maturity per se, but rather about the way the poet matures and grows in his work. Let me explain. As is well known, the author of Gertrudis and KRTU had done and continued to do a great deal of writing for the general public - of articles and essays - as well as cultural and political organizing. It is also known that when this same writer made his re-entry into the world of the printed word, around 1950, he had to limit himself to poetry or prose poetry. And so, this man who, before the civil war, had devoted himself to writing for the public about public issues (as well as publishing splendid books of prose poetry which scandalized certain of his contemporaries), after the war (and thus as a more mature writer) had to restrain himself and keep quiet. Later, when he began publishing again, the only path open to him was creative writing in the strict sense of the world. So it is not surprising that his poetry would become more conceptual, more ideological, with more of a tendency to tell a story, to give more details and from a closer vantage point. 
Both Gabriel Ferrater and Josep Romeu have shown us that Foix's poetry, in more than one case (and especially after the war) is both an account of, and an elaboration of, real facts and events. ${ }^{6}$ Thus, the poet can take an item from a newspaper article or a snatch of conversation and recompose it, imaginatively, tendentiously into a work of fantasy. The prose poems in Noves de darrera bora (1966-1969) (Latest News) reflect this process which, to a certain extent, is just the opposite of that applied in Telegrames (1929-1932). In the latter, imagination and fantasy are translated into the journalistic language of a newspaper article, as in the case of the telegram which has just arrived in the newsroom and is included, virtually unchanged, in the next morning's edition. ${ }^{7}$ If what I have just suggested does not seem too far out of line, it is easy to find a relationship between respective dates of Noves de darrera hora and Telegrames, and the previously mentioned differences between Foix's preand post-war work.

Telegrames can be defined as brief narratives in apparently documentary style, of a vision, and insight, a fantastic quality (for example, a child born with "two multi-colored wings" with "a radiant face ... beautiful, almost unreal" which neither photographers nor artists can capture; a child whose mother lives off of charity and who refuses to give the father's name ...). ${ }^{8}$ We can find similar examples in all of Foix's books, but they appear most in Gertrudis and KRTU, as frequent parentheses, sometimes juxtaposed in such a way as to become themes which explore the unconscious, the limits of experience;

${ }^{6}$ Gabriel Ferrater in the prologue of Els lloms transparents, cit.; Josep Romeu in Serra d'Or, January 1973, 49-50.

7 These two collections appeared in the same book, Allò que no diu La Vanguardia, Barcelona, 1970.

${ }^{8}$ From Allò que no diu La Vanguardia, 57. 
in the other books, however, both of poetry and prose poetry, we see this same form of expression, though it is more integrated into the whole, as an expression of a thought, an idea, working towards a specific, more reasoned end (not, of course, in all cases, but there are examples of this). In any case, in all of the books, these parenthetical interjections form a sort of nucleus. They could be considered the "leavening" of the poem, the glitter that makes it sparkle, the image around which the poet consciously creates and gives shape to the poem. These nuclei appear, now and then, throughout Foix's work, as recurrent themes, though the style and context in each case is unique.

This could lead to a theory of the poetic nucleus as long as we are not too strict in our interpretation of the term. In Foix's work we would find these nuclei: a) within a poem, either prose or verse; b) as poetic preambles; c) standing on their own. With regard to what has been previously discussed, the poetic nucleus could consist of a real and external statement of fact or of an articulation of a dream, a vision, a product of the poet's fantasy.

We needn't belabor the point. If we read some of his poems - and reading is a prerequisite in speaking about literature we will see how difficult it is to isolate in a single poem the "pure, visionary interjection", if I may apply Gimferrer's words to this example. We can, on the other hand, find more than one which is a parenthetical interjection of pure reality. As far as other types of nuclei which have been mentioned, the poet, needless to say, controls their degree of purity or revelation, making them condensed, compact and abrupt, or wordier and more rhetorical, according to what the poet intends or perceives.'

9 Pere Gimferrer, La poesia..., cit., 39: also Giuseppe Sansone, "Nota als preàmbuls poètics de J. V. Foix", Poemes, 7, 1964, 5-6, although his treatment is not sufficiently detailed. 
When, at the age of ninety plus years, Foix was awarded the degree of doctor honoris causa by the University of Barcelona ${ }^{10}$ his speech at the ceremony consisted of the reading of thirty-six brief texts which he described in the following manner:

... voldria sotmetre a la vostra consideració la lectura d'uns quants textos que constitueixen nuclis de poema, enunciats poemàtics o cèl-lules líriques, inèdits, i que són formulacions i síntesis sobre el Real i el Rar, l'U i el Divers, l'Ultrason i l'Insòlit,

(... I would like to read you some texts which are nuclei of poems - poetic formulas or lyric cells - unpublished formulations and syntheses on the Real and the Rare, the Unique and the Various, the Ultrasleep and the Unexpected,)

(we can, then, it appears, identify these texts as the nuclei about which we have been speaking, and the fact that they deal with those abstract and opposing concepts which Foix mentions above seems to confirm the fact that sometimes they are visions and other times real, concrete facts...)

suscitades després del somni, en general al matí, partint d'un mot, una frase, una metàfora $o$ una imatge, que, empesos per una energia creadora interna, s'ordenen i s'estructuren en un conjunt verbal compacte i concís,

(which are inspired, following a dream and generally in the morning, by a word, a phrase, a metaphor or an image which, impelled by an internal creative energy, find the order and the structure which transforms them into a concise and compact grouping of words,)

(which the poet presents as an ordered grouping of words, the product of a creative process)

${ }^{10}$ Homenatge a Josep V. Foix amb motiu d'ésser-li conferit el grau de doctor bonoris causa, Universitat de Barcelona, 1984. 
en una breu creació lírica in ono, en un projecte dur i diamantí, que més endavant hauria d'ésser comentat i glossat en el poema llarg i pròpiament dit. Moltes cèl-lules líriques d'aquest estil figuren com a títols-prefaci de poemes meus ja publicats, com els de Les irreals omegues, i altres llibres encara.

(into a short, lyrical creation in ouo, a hard and solid blueprint to be elaborated in the poem proper. Many of these types of lyric cells serve as prefacetitles of my published poems in Les irreals omegues (The Unreal Omegas) and other collections.)

This is in keeping with what I said earlier about these nuclei being identified with prefaces to poems (not only in Les irreals omegues (The Unreal Omegas), but in Desa aquests llibres al calaix de baix (Store These Books in the Bottom Drawer) and On be deixat les claus... (Where Have I Left the Keys...) as well, none of which are homogeneous nor equally developed).

As compact and concise grouping of words, these texts enjoy a privileged position in the exegesis of Foix's work; through a close look at them we can identify certain writing mechanisms, certain syntactical and rhetorical forms of expression which, once part of a longer and more complex verse or prose poem, become diluted and more difficult to isolate.

Let's take a close look at the first of these nuclei:

Passen ocells brogents per les discoteques. Els pins que s'ajoquen, altívols, es decanten com si passés una fosca ventada. Algú inesperadament s'esbargeix entre els roserars amb un altaveu.

(Noisy birds pass through the discotheques. The lofty pines bed down for the night bending as though a dark gale were blowing. Somebody unexpectedly romps among the rose beds with a loud speaker.)

This text can be divided into three parts, according to punctuation and the changes in meaning; most, though not all, of 
these thirty-six nuclei follow this three-part form. On the other hand, the nuclei which preface prose poems in Noves de darrera hora (Latest News) and introduce the verse poems are generally not of this three-part form. In these latter cases the nuclei tend to have a more syntactically complex structure with clauses which are predicative, complementary or circumstantial, and make use of subordinate clauses but little use of strong punctuation. I would like to present two examples, the first, the preface to Poem XIII from Les irreals omegues and the second from Noves de darrera hora; both are as different from the first nucleus we looked at as they are from each other:

ENS HAVÍEM BANYAT A LA CATIVA I, A SOL COLGANT, CONTEMPLÀVEM, DESPRÉS D'HAVER FULLEJAT UNA VELLA CRÒNICA MEDIEVAL, COM TOT DE REIS ANTICS AMB AMPLES CAPES VERMELLES TENIEN LLUR ASSEMBLEA AL SERRAT DE CAP GROS.

(WE HAD BATHED IN THE BAY AND, AT SUNSET, WE CONTEMPLATED, HAVING LEAFED THROUGH AN OLD MEDIEVAL CHRONICLE, HOW MANY ANCIENT KINGS WITH THEIR FLOWING RED CAPES WERE HOLDING THEIR ASSEMBLY IN THE CAP GROS HILLS.)

On first reading, this text seems comprehensible, and so it is, but much of the point will be lost to the reader who does not know that it precedes a poem - the last one in the book which evokes the days of Catalonia's glorious maritime past. The very sea which the poet is contemplating (and in which, as he indicates, he recently bathed with others) is the setting of that glorious past, a sea which was, in days of old, Greek. As a result, the poem not only refers from time to time to freedom, to "winged liberties" and to "that which is just" but also uses Greek roots (such as "pèlag") and peppers the poem with 
"olympians", "medusas", "heroes", "laurels", "pythia", etc. An interesting note, along these same lines, is that the poet qualifies something as familiar as the "espardenya" (Catalan peasant sandal) as "Frigian". The preface, then, sets the scene for the poem, written one afternoon at dusk after leafing through a medieval Catalan chronicle; the imagination changes the landscape, summoning up the ancient kings who made that glorious past possible.

The second example is, as I already mentioned, a text from Noves de darrera bora, dedicated to the memory of Joan SalvatPapasseit:

Un pelegrí sicilià, víctima de tres budistes traficants d'heroïna, vigila, nit $\mathrm{i}$ dia, els aquàriums, i empaita els insectes alats amb una orquídia.

(A Sicilian pilgrim, victim of three Buddhist heroine dealers, guards the aquariums, day and night, and chases after winged insects with an orchid.)

The only feature in common between the first and second example is that they both involve two actions by the same subject. The second example does not, however, exhibit the same syntactical complexity as the other prefaces and, in addition, cannot be compared to anything else: it stands alone, without a poem. In many of the nuclei which appear in both of the abovementioned books we see a variation on this coordination of two actions: a period, or a semi-colon separates two different sentences, and introduces a change of subject. The preface to poem XII in Les irreals omegues, for example, is composed of three parts (like our original example) with three different subjects.

With the two periods, each part of the text becomes selfcontained; the lack of links between the parts or the use of contrasts (a contrasting clause appears, for example, in the pre- 
face to XIX of On be deixat les claus) gives a sense of interruption which, together with the change of subject, helps to create the surprise effect which Foix is always after; an effect of surprise and mystery. Returning to our first text, the "noisy birds" are to discotheques (their noise signifies the din of this type of establishment) as "dark gale" is to "pines" (the effect of the wind makes the trees bed down for the night, although that is not explicitly stated; we can also assume that the pines are bent because of the noise of the birds which is like a gale. Though the comparison is made, we can't be certain what the gale is being compared to, as there is no statement of exactly what is making the trees bend. The only other clue we have is the verb "passar", the subject of which was the birds, but is now the gale). The noise of the birds, the wind that bends the pines, seem to correspond in the third part of the text to the racket of a loudspeaker, and the discotheque and pines seem to correspond to the rose beds. These correspondences, which are imagined relationships, could not be established by looking only at the syntactical construction which, with the two breaks, changes the function of each element. Apparently, each of the parts says something different: if connections are made between the elements, they cannot necessarily be confirmed through a syntactical analysis. The text, then, opens up, becomes polyvalent, if not in terms of meaning - which is not meaning per se, but rather a system of correctly established relationships - then certainly in terms of the suggestions of possible meanings and the directions in which those suggestions may lead.

We can also see in the text the coexistence of man-made elements such as the discotheques or the loudspeaker (and the music or the noise of the loudspeaker) with natural elements (the birds, the pines, the wind, the rose beds). This coexist- 
ence of elements is typical in Foix's poetry; if we try to relate them, however, according to the system I constructed above we find, once again, that there is a lack of correspondence; there is another element of distortion which further disconcerts the reader. Between nature and culture - in the broad, generic sense of those terms - man appears: everyman and no-man, not this one, nor that one but anyone: "algú". The progression from third person plural to third person singular accompanies the progression from the birds and the pines to a person, and the adverb, "unexpectedly", stresses the character of this progression. This is a clear example of a typically Foixian text. ${ }^{11}$

Rhythm is another important element in these prose pieces; the meter is characteristic of Foix's verse with one difference, and that is the difficult balance he manages to achieve between wishing to convey a meaning - and the reinforcement of that meaning through certain elements - and keeping to the normal pattern of "standard" prose. This is a difficult subject to tackle and to do it true justice would require a close study and computation of the meter in Foix's verses. ${ }^{12}$ Perhaps, however, I can clarify my point through a brief analysis of the first part of the nucleus which we have been looking at: "passen ocells/brogents/ per les discoteques" is a grouping of twelve grammatical syllables, four of which - the first, the fourth, the sixth and the eleventh - are stressed with two pauses, which together have the value of one caesura, one following the fourth syllable and the other following the sixth. We can de-

${ }^{11}$ On nature/culture and on the concept of the Foixian man: Pere Gimferrer, La poesia..., cit., passim, and Carles Miralles, from Homenatge a J. V. Foix..., cit., 35-36, 39, 46-51.

12 Josep Romeu's remarks are quite apropos in the prologue to J. V. Foix's Del "Diari 1918", Barcelona, 1956. 
duce the following: the pause comes before and after the word "brogents", thus stressing this word; the second pause, the more important, divides this first part of the nucleus into two parts which are significantly different. In the first half we see three stressed syllables, one of which is the final syllable, while in the second part there is only one stressed syllable, the second to last. That means that the first part is structured as verse, and specifically, as a half-line of one of two verse forms most used by Foix and the "noucentista" poets: the decasyllabic and the alexandrine. In addition, it opens with a four-syllable foot composed of a trochee and an iamb, as in Ausias March's "sí com aquell" (from "Sol, i de dol," where the two commas serve to accentuate the intensity of the initial rhythm). Continuing, then, "brogents", which is a bi-syllabic iamb, rounds out the intense rhythm of the first part of this nucleus which can be read as a half-line of an alexandrine. The second part - "per les discoteques" - is anticlimactic, ending in a word stressed on the penultimate syllable and with a sequence of four unstressed syllables in a row: it is more pedestrian and antithetical to what preceded. Discotheques, however, do represent something - a place - much more ordinary and much less natural than noisy birds.

Poetic diction usually shuns sequences of four unstressed syllables as they tend to break the rhythm of the verse, and elsewhere Foix skillfully avoids this, alternating mono- and polysyllabics, or words stressed on the penultimate syllable with words stressed on the final syllable. Nevertheless, in this particular nucleus we find three such sequences, one in each of its three parts (in addition to the one cited above, "... es decan /ten/ com/ sil pas/sés ..." and "... algú il nes/ pe/ ra/ da/ ment ..."). Although, as I stated above, this results in everyday, conversational type of language, on the surface more hap- 
hazard, the use of this type of diction contrasts with Foix's poetic skill in combining words, in suggesting relationships outside syntactic meaning; he surprises the reader while skilfully creating atmosphere. This strategy is evident in the image of "Els pins que s'ajoquen, altívols, es decanten ..." (the lofty pines bed down for the night, bending ...); of course pine trees are lofty, but this is in opposition to the idea of finding shelter to sleep (ajocar-se), a verb which normally has an animal as its subject, moving from a vertical position (where we expect trees to remain) to a horizontal position. "Altívols" (lofty) is deliberately placed, separated by commas, between "s'ajoquen" and "es decanten" (bend), the latter verb already half-suggesting the presence of the wind, providing a connection to the flying birds of the first part.

The aim of these techniques is clear and straightforward; to elaborate purely and simply, yet in all their complexity, certain relationships, certain suggestions which, as Foix himself says, are contained in ouo, in the poem, and therefore, in being subject to a process of purification of expression rather than being free-flowing like the nucleus which generated them, poetry.

Let us turn our attention to the second of these nuclei:

Volen els corbs arran d'un sac de llibres; hem tingut por $\mathrm{i}$ hem provat inútilment de cremar-los. Espantats hem corregut plana endins com una fumera.

(The ravens fly around a sack of books; we were frightened and we tried in vain to burn them. We ran scared into the plain like a cloud of smoke.)

Again there are birds, but not the "ocells brogents" which pass through the discotheques; instead of discotheques, there is a sack of books (no libraries; books in a sack, suggesting some- 
thing clandestine) and instead of noisy birds, ravens, a symbol of death evoking images of corpses. Thus the books in sacks could be corpses, around which the ravens circle; an image, perhaps, of the end of the civilization of the book. In the first case noisy birds, the noise necessarily suggesting life, pass through discotheques; in the second ravens, representing death, gather over books piled up in a sack. ${ }^{13}$

Again the passage is in three parts, though here the first and second are separated by a semi-colon, which marks the change from the third person plural (the ravens) to the first person plural (the verb form "hem"), thus "we" are implicated in the image of ravens over a sack of books rather than "someone" ("algú") as in the previous passage. "We" are characterized by fear ("... hem tingut por ... Espantats ...") and this fear is underlined by the change from the generality of the present tense ("els corbs volen") to the immediacy of the perfect tense ("hem tingut por", "hem provat", "hem corregut"), which I interpret as a change in aspect rather than time. It is a significant change; the ravens fly, are flying and we have witnessed this at a specific time in the recent past and we reacted in a particular manner to this phenomenon, by trying to burn the books. The ravens remain active, they fly; we, initially, react passively, we are afraid, but this fear stimulates action, an attempt whose failure ("inútilment") leads to further action (the third part of the passage); this final act, our fleeing into

${ }^{13}$ The theme of "the illness suffered by books" is recurrent in Foix's work as seen in Gertrudis; in the poem which begins "Que hagin aparedat portals i finestres ..." (That they closed doors and windows ...) can be read: "... avui he vist saltar de cop els lloms dels meus llibres i he descobert la putrefacció cancerosa que destrossa llurs entranyes" (... today I saw the spines of my books suddenly fall off and I discovered the cancer that is rotting their entrails). 
the plain like a cloud of smoke, corresponds to the flight of the raven. Why, then, the choice of a cloud of smoke? The intention here is to show that we have transformed ourselves, unexpectedly, into the smoke that we failed to create when we failed to burn the books.

So, the image changes from ravens to "we", from flying to fleeing, from books which fail to go up in smoke to our running like a cloud of smoke. Culture, in the form of the books, is shown to be substantial, it stands up to man, to us, who are insubstantial, smoke. This passage, like many other of Foix's works, becomes a parable. We found the books ignominiously piled up in a sack and we saw the ravens; we were afraid and we felt guilty, we tried to destroy the evidence of the crime, but culture has prevailed, our attempt to destroy it, to burn the books, serving only to demonstrate that we are ephemeral, that we are smoke.

As we have seen, these two nuclei, our judgment of which is inevitably colored by the fact that they are by Foix (and thus preceeded by a rich, varied and respected set of works), include themes, ideas, even words which evoke Foix's earlier works. The danger of overloading the reader with such observations is, I believe, offset by the enrichment of the texts which they provide, while, at the same time, aiding our comprehension of the poet's earlier works. Perhaps this will be better appreciated if we consider another of these nuclei, the eighth of these lyric cells:

Desaven maniquins al fons del soterrani. Entre ferralla vella $\mathrm{i}$ caps de gegant abonyegats. El guardià recollia rocs figuratius a les voreres del passeig.

(They store mannequins at the back of the cellar. Among old scrap-iron and dented giant-heads. The warden collected figurative rocks from the sidewalk.) 
Mannequins, dummies, have been recurrent themes in Foix's poetry right from the start. In a poem in $K R T U^{14}$ there is a kind of giant ("homenàs") who blocks the front door and refuses to let the poet out of his house despite the latter's many attempts to persuade him. Having established that the figure is artificial, manufactured, the poet addresses it as follows: "Et conec, maniquí, restaré sempre més sota la teva guarda" (I know you, mannequin, I will remain under your protection forever more). Apart from the obvious "possible psychoanalytical connotations of this image", also to be found in one of the painter de Chirico's periods, ${ }^{15}$ there is the curious matter of the connection between the mannequin ("gegant", "homenàs", something artificial, as "el cartó-pasta de la seva testa regalima encara vernís i el seu bigoti roig és pintat de fresc" — the papiermaché head still drips varnish and its red moustache is freshly painted) and the idea of guarding, a type of association which appears to recur in our passage, where again there is a warden of some kind. Though we do not know his function, we do know his activity at the time in question, and it is precisely this activity which is the most surprising element of the nucleus.

Apart from the mannequin, we find another recurrent theme in Foix's work, that of the "soterrani", the cellar or basement, possibly a garage, whose physical form indicates an obsession with low ceilings, with fear of suffocation; it also appears, in other works, as a place where marvels are witnessed, where Matilde and Madroneta undress (the former behind the scrap-iron store in the railway-station, the latter in the garage). ${ }^{16}$

${ }^{14}$ The poem is that which begins "Palplantat a la porta ..." (Stopped dead at the door ...).

15 Pere Gimferrer, La poesia..., cit., 12-13.

16 These and another woman who also undresses, Pere Gimferrer, $L a$ poesia..., cit., 41. 
Thus the reader finds, in "Desaven maniquins al fons del soterrani. Entre ferralla vella i caps de gegant abonyegats", references to recurrent themes in Foix's work: dummies and giant-heads kept at the back of the cellar among the scrapiron, all of it worn-out, useless; the giant-heads are dented, the scrap-metal is old; this is a desolate setting, evoking images of death; a place which is entered, where things are left, but from which, it seems, nothing leaves; the back of the cellar is a dead-end, reminiscent of a tomb. The theme is similar to that of the station, the scrap-iron deposit where, we are told, Matilde undressed, in Foix's recent L'estació, published with etchings by Antoni Tàpies. ${ }^{17}$ It is a theme marked by death and the mysteries of death, in other words, by a sense of loss, the suspicion that everything cannot end in nothingness. Foix's poetry appreciates the contrast, polarity; it combines, juxtaposes and confuses elements which, according to reality as perceived by the majority of human beings, are in direct opposition. These places (or the means of getting there, trains or trams, for example) have inspectors or wardens, some sort of order to be maintained which requires some form of authority. ${ }^{18}$ We have already come across mannequins serving this function in Foix's work. However the sudden appearance of the guard comes as a surprise as it introduces a change; a new sentence in which a particular person does something apparently unrelated to what has gone before, a sudden break from the previous verb form, a third person plural ("Desaven") whose subject is not specified: they, whoever they are, were engaged in putting things away while the warden was collect-

${ }^{17}$ A book club edition published by Taché Editor, Barcelona, in December 1984.

${ }^{18}$ Symbols of authority appear in "Sense simbolisme", "Plaça Catalunya-Pedralbes" and "Conte de Nadal" from Gertrudis. 
ing things. This parallel seems to imply a connection between the actions of these persons unknown and those of the warden. Of course this connection need not be one of strict logical equivalence; it is sufficient to point out that chance, which, with particular groups of words or in certain situations can produce figurative meanings which operate on the scrap-iron, the giant-heads or the mannequins (or on "la carcassa d'un bou malmesa pel temps" - the ox carcass rotted by time, to quote from another of Foix's poems) ${ }^{19}$ can also have given the rocks, collected by the warden, the attributes which make them, according to the poet, figurative.

Thus the poet's strategy here is to use polarity: "They"/the warden, leave/collect, mannequins/rocks. This opposition is reinforced rhythmically and graphically. There is also a syntactic and a semantic correspondence and opposition between the first and the last sentence: the third sentence begins with the third-person singular subject ("el guardià") whereas the first begins with the verb, the morpheme of "desaven", an (unidentified) third person plural serving to reinforce the contrast with "recollia"; then come the respective objects, "mannequins" on the one hand and "rocs figuratius" on the other; finally there is, in each case, an indirect object, both locatives and both followed by adnominals ("al fons del soterrani", "a les voreres del passeig"). Between these two sentences (which are symmetrical opposites) is another sentence which, in fact, is a circumstantial complement of the first, but which the poet has wished to emphasize graphically by putting it between periods.

Furthermore, the meter of the second sentence does not rad-

${ }^{19}$ From the second poem in Del "Diari 1918" where Matilda undresses. 
ically contrast with that of the first, which is an alexandrine, whereas the third sentence is a clear contrast, both rhythmically and in length.

This analysis can serve to confirm, on the other hand, the recurrence and polyvalence in different contexts of the same themes, and on the other hand, the equivalence while in opposition, of certain images. This is a deliberate strategy which forms the basis of the syntax and rhythm of the sentences. In other cases, the intended meaning is more clearly defined, and the nucleus can be considered a further elucidation of a recurrent Foixian theme. Thus the ninth in our series, which deals with the theme of the present-day relevance of the ancient in contrast to incomprehension of the present:

Llegim savis antics a la claror d'una espelma. Els rellegim com si fossin novetats. Un eco de veus perdudes entrava pels finestrals. Llur llenguatge ens era desconegut.

(We read the ancient masters by the light of a candle. We reread them as if they were new. An echo of lost voices was coming in through the windows. Their language was unknown to us.)

In the first place, we are presented with a first person plural; "we", which includes "I", are enshrined as agents, thanks to the morpheme of the verb: we are reading, our action being directed at the books of the ancient masters, books we had already read, but on rereading, are able to appreciate their originality, their novelty. This is the message of the first two sentences. If we read the second two, we find that the two halves of the nucleus are symmetric and also in opposition to one another. In the second two sentences "we" are no longer agents, here an echo of "lost" voices (other peoples', not ours) comes in (whether we like it or not, we have no role here) 
through the windows; whereas before when we read, we understood, now we understand nothing of the echoes. The tense has changed from present to imperfect but this does not indicate a difference in time even though the third sentence has the tone and rhythm of romance verse: "Un eco de veus perdudes/entrava pels finestrals". ${ }^{20}$ I shall not dwell on this point, even though the subject of Foix's use of tenses and "consecutio", the sequence of tenses, is both interesting and revealing; suffice it to say that the use of the imperfect indicates the initial and then continued occurrence of an event during the time when the action described at the beginning of the passage is taking place, i.e., while we were reading.

In an understandable and direct way, this text partially modifies a Foixian theme; the synthesis of the old and the new, of the past and the present: the underlying opposition is not between the two verbs, but rather between the reading of the ancient masters and the voices coming through the windows; this contrast is irreconcilable, which perhaps accounts for the anachronism "by the light of a candle". Elsewhere Foix proposes connections between apparently unconnected ideas and objects from the ancient and modern world, thus questioning prevailing attitudes. Here, on the other hand, he merely contrasts them: he asserts the incomprehensibility of the present, of those voices which can come in at any time, through any window, and which speak a language which is, quite simply, unknown to him. This constitutes an important variation on an established theme.

I would like to comment briefly on another of these nuclei,

${ }^{20}$ Among other instances in Foix's work, poem III of $O n$ he deixat les claus... could be pointed to as an example of the use of two tenses (present and imperfect) which are not in opposition. 
of interest both because it deals with a basic Foixian theme, the limits of life, of human experience, related to the image of the basement or station, and because it sheds further light on Foix's use of verb tenses; it is number 33 of the series:

Passen el túnel els usurers corbats amb un sac de palla negra. Nosaltres havíem parat el paraigua i passàrem el túnel ulls tancats. El sol aparegué amb singulars coloracions.

(The usurers went through the tunnel bent under sacks of black straw. We had opened our umbrella and we went through the tunnel with our eyes closed. The sun appeared with unique coloring.)

Again we find oppositions between "they" and "we", between the present and the past; here different verb tenses are used to express the past, but again, the opposition is not a question of time. "Passàrem" (we) and "aparegué" (the sun) refer to events which took place at particular moments (and in a particular way; in the case of the sun, rather ambiguously "with unique coloring", in the case of our passage through the tunnel, apparently even more improbably, after we had opened the umbrella).

Here the tunnel, a familiar image of darkness and low ceilings, refers not so much to life in its general or biological sense (by which I mean the idea of death at the end of the tunnel) as to everyday life, everyday duties, where the poet clearly distinguished between passing through bent under a heavy weight, the interest obtained by the usurers (thus the straw they carry is black), and passing through with eyes closed, i.e. accepting the darkness, assimilating it; we have opened the umbrella, an incongruous, contradictory image, but which here emphasises our levity; compared to the grave usurers, bent double under the weight of their usury, we are 
light, the umbrella stretching upwards (pointlessly, in a tunnel, if it is to be used for rain or sun). This seems to imply, then, that only for those who pass through the tunnel with their eyes closed, with levity (us, according to the poem) does "the sun appear with unique coloring".

The aim of this paper has been to discuss and clarify the nature and meaning of these nuclei, pointing out certain easily identifiable bases for analysis and interpretation and situating these pieces within the complete body of Foix's work. AIthough incomplete, this first attempt to facilitate the interpretation of these texts aims to draw attention to their importance, which in terms of certain aspects of Foix's work, is crucial, i.e., to what extent the verb configurations expressing these ideas, images or themes can be considered representative or symptomatic of the creative process ("the process of development of a poem", in Foix's words) ${ }^{21}$ of a whole series of poets (or creators, for they need not be, strictly speaking, poets), perhaps particularly those who explore the fragmentation, the lack of internal cohesion, of contemporary man.

Foix gives us a basis from which to follow the process by which introspection, an immersion in the half-waking, halfsleeping world inside each of us, converts experience, words, images or ideas into a description (or narration) of a landscape at times hostile, at times inherently incomprehensible but

21 In a letter which I received in August of last year, Foix justified his choice of poetic nuclei as the subject of his speech on the occasion of his investiture as Honoris Causa Doctor at the University of Barcelona. He said, in terms much like those which I have cited in this article: "it seems to me - and I'm not sure if I'm right - that it would be an interesting idea to approach the idea of the process of development of a poem through an image, an idea or a word which comes to me in the early hours of the morning." 
always externalized. It is more than a landscape, it is a stage, a stage filled with objects, inhabited by people. This setting which originates deep in the individual is projected onto the outside world, but not a world made up of everyday objects which are what they seem to be, what we all interpret them as being, but made up of objects which are not what they appear to be, for example the "figurative" rocks (suggesting that they appear to be something other than rocks) which the warden was collecting. This is a world where man also is clearly figurative, in the sense that he is variously reified in unexpected ways (giants or mannequins, prisoners in a cellar or passengers on an unreal tram) reminding us of the words of the poet in his introduction to poem VI of Les irreals omegues when he talks of "la meva pròpia irrealitat" (my own unreality), or perhaps even more, of that "llegenda clandestina" which stated that "sempre som en existència d'altri" (we are always in someone else's existence), a legend "gravada al peu d'unes figures que imitaven, rústegues, uns mísers infants" (engraved at the foot of figures which imitated, stiffly, miserable children), another Foixian theme related to a return to childhood, and in particular the fact that the child everyone has been is almost like a separate person. $^{22}$

The issue is the blurring of personality, both between oneself and others, and between oneself and one's former selves. A series of interchangeable masks. The world is a stage, and it is a fact that we all wear masks ("màscara", or "carota", the more colloquial term in Catalan, suggesting costumes and fun).

I trust that what I have written has been sufficiently stimulating and understandable for the reader to enjoy this last lyric cell $n^{\circ} 23$ without comment or explanations. This is an ap-

22 The cited text is the preamble of poem V from Les irreals omegues. 
propriate piece on which to end my explorations on Foixian prose, as I believe it lends support to the ideas expounded above.

Posaven els peus a la pregonesa dels estanys quan la lluna clareja. Algú cantava cançons novelles que l'eco repetia. Vam posar-nos, de nou, la carota.

(They were putting their feet on the bottom of the lakes when the moon shines. Somebody was singing new songs which the echo repeated. We put our masks back on.)

CARLES MIRALLES UNIVERSITAT DE BARCELONA

Translation by Ita Roberts and Francis Humble 